\title{
Sawhorse-type diruthenium tetracarbonyl complexes containing porphyrin-derived ligands as highly selective photosensitizers for female reproductive cancer cells
}

\author{
Frédéric Schmitt $\cdot$ Mathieu Auzias $\cdot$ Petr Štěpnička \\ Yoshihisa Sei · Kentaro Yamaguchi · Georg Süss-Fink • \\ Bruno Therrien · Lucienne Juillerat-Jeanneret
}

Received: 7 January 2009/Accepted: 6 February 2009/Published online: 25 February 2009

(c) SBIC 2009

\begin{abstract}
Diruthenium tetracarbonyl complexes of the type $\left[\mathrm{Ru}_{2}(\mathrm{CO})_{4}\left(\mu_{2}-\eta^{2}-\mathrm{O}_{2} \mathrm{CR}\right)_{2} \mathrm{~L}_{2}\right]$ containing a $\mathrm{Ru}-\mathrm{Ru}$ backbone with four equatorial carbonyl ligands, two carboxylato bridges, and two axial two-electron ligands in a sawhorse-like geometry have been synthesized with porphyrin-derived substituents in the axial ligands $\left[\mathbf{1}: \mathrm{R}\right.$ is $\mathrm{CH}_{3}$, $\mathrm{L}$ is 5-(4-pyridyl)-10,15,20-triphenyl-21,23H-porphyrin], in the bridging carboxylato ligands $\left[2: \mathrm{RCO}_{2} \mathrm{H}\right.$ is 5-(4carboxyphenyl)-10,15,20-triphenyl-21,23H-porphyrin, $\mathrm{L}$ is $\mathrm{PPh}_{3} ; 3: \mathrm{RCO}_{2} \mathrm{H}$ is 5-(4-carboxyphenyl)-10,15,20-triphenyl-21,23H-porphyrin, $\mathrm{L}$ is 1,3,5-triaza-7-phosphatricyclo [3.3.1.1]decane], or in both positions $\left[4: \mathrm{RCO}_{2} \mathrm{H}\right.$ is 5 -(4carboxyphenyl)-10,15,20-triphenyl-21,23H-porphyrin, $\mathrm{L}$ is
\end{abstract}

F. Schmitt · L. Juillerat-Jeanneret $(\bowtie)$

Institut Universitaire de Pathologie, CHUV,

Bugnon 25,

1011 Lausanne, Switzerland

e-mail: lucienne.juillerat@chuv.ch

M. Auzias · G. Süss-Fink · B. Therrien $(\bowtie)$

Institut de Chimie,

Université de Neuchâtel,

Case postale 158 ,

2009 Neuchâtel, Switzerland

e-mail: bruno.therrien@unine.ch

P. Štěpnička

Department of Inorganic Chemistry,

Faculty of Science,

Charles University,

Hlavova 2030, 12840 Prague 2,

Czech Republic

Y. Sei · K. Yamaguchi

Laboratory of Analytical Chemistry,

Tokushima Bunri University,

Shido, Sanuki,

Kagawa 769-2193, Japan
5-(4-pyridyl)-10,15,20-triphenyl-21,23H-porphyrin]. Compounds 1-3 were assessed on different types of human cancer cells and normal cells. Their uptake by cells was quantified by fluorescence and checked by fluorescence microscopy. These compounds were taken up by human HeLa cervix and A2780 and Ovcar ovarian carcinoma cells but not by normal cells and other cancer cell lines (A549 pulmonary, Me300 melanoma, PC3 and LnCap prostate, KB head and neck, MDAMB231 and MCF7 breast, or HT29 colon cancer cells). The compounds demonstrated no cytotoxicity in the absence of laser irradiation but exhibited good phototoxicities in HeLa and A2780 cells when exposed to laser light at $652 \mathrm{~nm}$, displaying an $\mathrm{LD}_{50}$ between 1.5 and $6.5 \mathrm{~J} / \mathrm{cm}^{2}$ in these two cell lines and more than $15 \mathrm{~J} / \mathrm{cm}^{2}$ for the others. Thus, these types of porphyric compound present specificity for cancer cell lines of the female reproductive system and not for normal cells; thus being promising new organometallic photosensitizers.

Keywords Photosensitizer - Ruthenium - Cancer . Anticancer agent $\cdot$ Bioorganometallic

\section{Introduction}

Photodynamic therapy is a modality of treatment already used in the clinic for cancer treatment [1-4]. It involves a nontoxic photoactivable dye called a "photosensitizer" in combination with harmless visible light of a specific wavelength to excite the photosensitizer. The photosensitizer reaches a high-energy triplet state which reacts with cellular oxygen to form toxic reactive oxygen species such as singlet oxygen and oxygen radicals which will oxidize cellular nuclei, fatty, and amino acids. The photosensitizers commonly bear a tetrapyrrolic ring such as porphyrins, 
chlorins, or bacteriochlorins and have been shown to concentrate in cancer cells $[3,5,6]$. On the other hand, organometallic drugs, especially platinum derivatives, are commonly used in cancer therapy [7-9]. However, significant problems associated with platinum compounds limit their applicability, including a high general toxicity and drug resistance by several types of cancer $[10,11]$. Some progress has been made to overcome these limitations with other organometallics such as ruthenium-based agents [12]. Ruthenium is an attractive alternative to platinum since ruthenium compounds are known to display less general toxicity than their platinum counterparts, but are also able to interact with DNA and proteins [13]. Moreover, ruthenium derivatives are believed to be taken up by cells via the transferrin receptor system in particular and present some selectivity for cancer cell lines [12].

Combining both an organometallic group with a porphyric photosensitizing moiety could therefore represent a promising approach. Complexes of porphyrins coordinated to platinum groups were developed mainly by Lottner et al. a few years ago and show some promise [14-18]. More recently, we have coordinated arene-ruthenium(II) moieties to pyridylporphyrins and such complexes showed good cytotoxicities and phototoxicities toward human melanoma cancer cells $[19,20]$. In this study, we have chosen the diruthenium tetracarbonyl structure as the organometallic agent and backbone of the complexes. These sawhorse-type diruthenium complexes have been known since 1969, when J. Lewis and co-workers [21] reported the formation of $\left[\mathrm{Ru}_{2}(\mathrm{CO})_{4}\left(\mu_{2}-\eta^{2}-\mathrm{O}_{2} \mathrm{CR}\right)_{2}\right]_{n}$ polymers by refluxing $\left[\mathrm{Ru}_{3}(\mathrm{CO})_{12}\right]$ in the corresponding carboxylic acid $\left(\mathrm{HO}_{2} \mathrm{CR}\right)$, and the depolymerization of these materials in coordinating solvents to give dinuclear complexes of the type $\left[\mathrm{Ru}_{2}(\mathrm{CO})_{4}\left(\mu_{2}-\eta^{2}-\mathrm{O}_{2} \mathrm{CR}\right)_{2} \mathrm{~L}_{2}\right], \mathrm{L}$ being acetonitrile, pyridine, or other two-electron donor ligands (Structure 1).

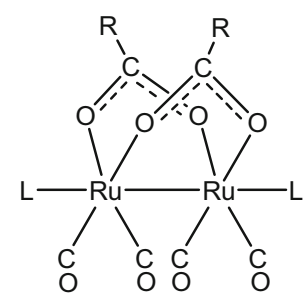

\section{Structure 1}

Herein, we describe the synthesis, the spectroscopic characterization, the electrochemical behavior, and the biological activity in human normal fibroblastic cells and in many types of human cancer cells of diruthenium tetracarbonyl complexes of the type $\left[\mathrm{Ru}_{2}(\mathrm{CO})_{4}\left(\mu_{2}-\eta^{2}-\mathrm{O}_{2}\right.\right.$ $\left.\mathrm{CR})_{2} \mathrm{~L}_{2}\right]$ containing porphyrin substituents: $\left[\mathrm{Ru}_{2}(\mathrm{CO})_{4}\right.$
$\left.\left(\mu_{2}-\eta^{2}-\mathrm{O}_{2} \mathrm{CCH}_{3}\right)_{2}\left(\mathrm{C}_{43} \mathrm{H}_{29} \mathrm{~N}_{5}\right)_{2}\right] \quad(\mathbf{1}), \quad\left[\mathrm{Ru}_{2}(\mathrm{CO})_{4}\left(\mu_{2}-\eta^{2}-\mathrm{O}_{2}\right.\right.$ $\left.\left.\mathrm{CC}_{44} \mathrm{H}_{29} \mathrm{~N}_{4}\right)_{2}\left(\mathrm{PPh}_{3}\right)_{2}\right](2),\left[\mathrm{Ru}_{2}(\mathrm{CO})_{4}\left(\mu_{2}-\eta^{2}-\mathrm{O}_{2} \mathrm{CC}_{44} \mathrm{H}_{29} \mathrm{~N}_{4}\right)_{2}\right.$ (pta) $)_{2}$ (pta is 1,3,5-triaza-7-phosphatricyclo[3.3.1.1]decane) (3), and $\left[\mathrm{Ru}_{2}(\mathrm{CO})_{4}\left(\mu_{2}-\eta^{2}-\mathrm{O}_{2} \mathrm{CC}_{44} \mathrm{H}_{29} \mathrm{~N}_{4}\right)_{2}\left(\mathrm{C}_{43} \mathrm{H}_{29} \mathrm{~N}_{5}\right)_{2}\right]$ (4).

\section{Experimental}

Materials and methods

All manipulations were carried out by conventional Schlenk techniques under a nitrogen atmosphere. Organic solvents were dried, degassed, and saturated with nitrogen prior to use. All reagents were purchased from Aldrich, Fluka, and Porphyrin Systems and used as received. Dodecacarbonyltriruthenium [22] and 1,3,5-triaza-7phosphatricyclo[3.3.1.1]decane (pta) [23] were prepared according to published methods. NMR spectra were recorded at $25{ }^{\circ} \mathrm{C}$ using a Bruker $400 \mathrm{MHz}$ spectrometer. IR spectra were recorded using a PerkinElmer $1720 \mathrm{X}$ Fourier transform IR spectrometer $\left(4,000-400 \mathrm{~cm}^{-1}\right)$. UV-vis absorption spectra were recorded with a Uvikon 930 spectrophotometer. Microanalyses were performed by the Laboratory of Pharmaceutical Chemistry, University of Geneva (Switzerland). Electrospray mass spectra studies were realized using an APEX II Fourier transform ion cyclotron resonance mass spectrometer equipped with a 9.4-T superconducting magnet (Bruker Daltonics). Electrochemical measurements were carried out with a computer-controlled $\mu$ AUTOLAB III multipurpose polarograph (Eco Chemie, The Netherlands) at room temperature using a Metroohm three-electrode cell with a rotating platinum disc electrode (AUTOLAB RDE; 3-mm diameter) as the working electrode, a platinum sheet auxiliary electrode, and an $\mathrm{Ag} / \mathrm{AgCl}$ reference electrode (3 M $\mathrm{KCl}$ ). The compounds analyzed were dissolved in dichloromethane (Fluka, absolute; declared $\mathrm{H}_{2} \mathrm{O}$ content $0.005 \%$ or less) to give a solution containing $5 \times 10^{-4} \mathrm{M}$ of the analyte and $0.1 \mathrm{M} \mathrm{Bu}_{4} \mathrm{NPF}_{6}$ (Fluka, purissimum for electrochemistry). In the case of poorly soluble compounds, saturated solutions were used. The solutions were degassed and saturated with argon prior to the measurement and then kept under an argon blanket. The redox potentials are given relative to an internal ferrocene/ferrocenium reference. Quantum yields were assessed after excitation at $414 \mathrm{~nm}$ as previously described [20]. Fluorescence quantum yields at $648 \mathrm{~nm}$ were determined using a PerkinElmer LS50 spectrofluorometer. The singlet oxygen quantum yield was determined using the singlet oxygen specific fluorescence at 1,270 nm monitored by a liquid-nitrogen-cooled germanium detector (model EO-817L, North Coast Scientific) from the DCPR facility, ENSIC, Nancy, France. 
Synthesis of complexes 1-4

A solution of $\left[\mathrm{Ru}_{3}(\mathrm{CO})_{12}\right]$ (1 equiv, typically $15-50 \mathrm{mg}$ ) and 3 equiv of the corresponding acid [5 $\mathrm{mg}$ of acetic acid for 1, $100 \mathrm{mg}$ of 5-(4-carboxyphenyl)-10,15,20-triphenyl21,23H-porphyrin for $\mathbf{2}, 155 \mathrm{mg}$ of 5-(4-carboxyphenyl)10,15,20-triphenyl-21,23H-porphyrin for $\mathbf{3}, 55 \mathrm{mg}$ of 5-(4-carboxyphenyl)-10,15,20-triphenyl-21,23H-porphyrin for 4] in dry tetrahydrofuran (THF; $30 \mathrm{~mL}$ ) were heated at $120{ }^{\circ} \mathrm{C}$ in a pressure Schlenk tube for $18 \mathrm{~h}$. Then the solvent was evaporated to give a purple or brown residue which was dissolved in THF and 3 equiv of the appropriate ligand $\mathrm{L}$ [L is 5-(4-pyridyl)-10,15,20-triphenyl-21,23Hporphyrin for 1 and $4, \mathrm{PPh}_{3}$ for 2 , and $\mathrm{L}$ is pta for 3 ] was added. The solution was stirred at room temperature for $2 \mathrm{~h}$, the solution was evaporated, and the product was isolated by precipitation from a THF/hexane mixture. All products were obtained as air-stable purple crystalline powders.

Spectroscopic data for $\mathbf{1}$

Yield: $55 \mathrm{mg} \quad(83 \%) .{ }^{1} \mathrm{H} \quad \mathrm{NMR} \quad\left(400 \mathrm{MHz}, \mathrm{CDCl}_{3}\right)$ $\delta=-2.75(\mathrm{~s}, 4 \mathrm{H}, \mathrm{NH}), 2.37$ (s, $\left.6 \mathrm{H}, \mathrm{CH}_{3}\right), 7.76-7.86(\mathrm{~m}, 18 \mathrm{H}$, $\left.\mathrm{C}_{6} H_{5}\right), 8.23-8.27\left(\mathrm{~m}, 12 \mathrm{H}, \mathrm{C}_{6} H_{5}\right), 8.38\left(\mathrm{~d}, 4 \mathrm{H},{ }^{3} \mathrm{~J}=6 \mathrm{~Hz}\right.$, $\left.\mathrm{H}_{\text {pyr }}\right), 8.90\left(\mathrm{~s}, 8 \mathrm{H}, \mathrm{H}_{\text {porph }}\right), 8.99$ (s, $\left.8 \mathrm{H}, \mathrm{H}_{\text {porph }}\right), 9.24(\mathrm{~d}, 4 \mathrm{H}$, $\left.{ }^{3} J=6 \mathrm{~Hz}, \mathrm{H}_{\text {pyr }}\right) .{ }^{13} \mathrm{C}\left\{{ }^{1} \mathrm{H}\right\}$ NMR $\left(100 \mathrm{MHz}, \mathrm{CDCl}_{3}\right)$ $\delta=24.27\left(\mathrm{CH}_{3}\right), 94.30,99.92,101.59,115.25,120.97$, $121.48\left(C_{\text {porph }}\right), 126.92\left(C_{6} \mathrm{H}_{5}\right), 126.98\left(C_{\text {porph }}\right), 128.10$ $\left(C_{6} \mathrm{H}_{5}\right), 134.74,130.95\left(C_{\text {porph }}\right), 134.73\left(C_{6} \mathrm{H}_{5}\right), 137.78$, 142.05, 150.33 ( $\left.C_{\text {porph }}\right), 187.34$ (COO), $204.45(C O)$. IR $\left(\mathrm{CaF}_{2}, \mathrm{~cm}^{-1}\right): v_{(\mathrm{CO})} 2,024.12 \mathrm{vs}, 1,974.10 \mathrm{~m}, 1,940.80 \mathrm{vs}$, $v_{(\mathrm{OCO})} 1,574.14 \mathrm{~s}$. Anal. calcd for $\mathrm{C}_{94} \mathrm{H}_{64} \mathrm{~N}_{10} \mathrm{O}_{8} \mathrm{Ru}_{2}$ (1,663.72): C, 67.86; H, 3.88; N, 8.42. Found: C, 67.54; H, 3.56; N, 8.06. Electrospray ionization mass spectrometry (ESI-MS) (positive mode): 1,665.32 $[\mathrm{M}+\mathrm{H}]^{+}$.

Spectroscopic data for $\mathbf{2}$

Yield: $98 \mathrm{mg}$ (59\%). ${ }^{1} \mathrm{H} \quad \mathrm{NMR} \quad\left(400 \mathrm{MHz}, \mathrm{CDCl}_{3}\right)$ $\delta=-2.75(\mathrm{~s}, 4 \mathrm{H}, \mathrm{NH}), 7.46-7.55\left(\mathrm{~m}, 18 \mathrm{H}, \mathrm{H}_{\mathrm{PPh} 3}\right), 7.60(\mathrm{~d}, 4 \mathrm{H}$, $\left.\mathrm{C}_{6} \mathrm{H}_{4} \mathrm{COO},{ }^{3} \mathrm{~J}=8 \mathrm{~Hz}\right), 7.77-7.84\left(\mathrm{~m}, 20 \mathrm{H}, \mathrm{H}_{\mathrm{porph}}\right), 7.86-$ $7.90\left(\mathrm{~m}, 12 \mathrm{H}, \mathrm{H}_{\mathrm{PPh} 3}\right), 8.01\left(\mathrm{~d}, 4 \mathrm{H}, \mathrm{C}_{6} H_{4} \mathrm{COO},{ }^{3} \mathrm{~J}=8 \mathrm{~Hz}\right)$, 8.24-8.26 (m, 12H, $\left.\mathrm{H}_{\text {porph }}\right), 8.86-8.91\left(\mathrm{~m}, 14 \mathrm{H}, \mathrm{H}_{\text {porph }}\right)$. ${ }^{13} \mathrm{C}\left\{{ }^{1} \mathrm{H}\right\}$ NMR $\left(100 \mathrm{MHz}, \mathrm{CDCl}_{3}\right) \delta=119.59,120.42$, $120.53,126.88,127.93,128.61,128.78,128.82,128.87$, $130.04,133.04,133.65,133.81,133.97,134.10,134.16$, $134.22,134.69,142.29,145.50\left(C_{\text {porph }}\right), 181.23(C O O)$, 205.78 (CO). ${ }^{31} \mathrm{P} \quad\left\{{ }^{1} \mathrm{H}\right\} \quad \mathrm{NMR} \quad\left(162 \mathrm{MHz}, \mathrm{CDCl}_{3}\right)$ $\delta=15.99$ ppm. IR $\left(\mathrm{CaF}_{2}, \mathrm{~cm}^{-1}\right): v_{(\mathrm{CO})} 2,024.90 \mathrm{vs}$, $1,980.00 \mathrm{~m}, 1,952.73 \mathrm{vs}, v_{(\mathrm{OCO})} 1,589 \mathrm{~s}$. Anal. calcd for $\mathrm{C}_{130} \mathrm{H}_{88} \mathrm{~N}_{8} \mathrm{O}_{8} \mathrm{P}_{2} \mathrm{Ru}_{2} \cdot 5 \mathrm{H}_{2} \mathrm{O}$ (2,244.3): C, 69.57; H, 4.40; N, 4.99. Found: $\mathrm{C}, 69.24 ; \mathrm{H}, 4.55 ; \mathrm{N}, 4.87$. ESI-MS (positive mode): $2,154.45[\mathrm{M}+\mathrm{H}]^{+}, 1,893.34\left[\mathrm{M}-\mathrm{PPh}_{3}+\mathrm{H}\right]^{+}$, $1,077.73[\mathrm{M} / 2+\mathrm{H}]^{+}$.

Spectroscopic data for $\mathbf{3}$

Yield: $168 \mathrm{mg}$ (74\%). ${ }^{1} \mathrm{H}$ NMR $\left(400 \mathrm{MHz}, \mathrm{CDCl}_{3}\right)$ : $\delta=-2.74(\mathrm{~s}, 4 \mathrm{H}, \mathrm{NH}), 4.67\left(\right.$ br s, $\left.12 \mathrm{H}, \mathrm{CH}_{2}\right), 4.78(\mathrm{~m}$, $\left.12 \mathrm{H}, \mathrm{CH}_{2}\right), 7.73-7.82\left(\mathrm{~m}, 20 \mathrm{H}, \mathrm{H}_{\text {porph }}\right), 8.23(\mathrm{~d}, 12 \mathrm{H}$, $\left.\mathrm{H}_{\text {porph }}\right), 8.32\left(\mathrm{~d}, 4 \mathrm{H}, \mathrm{C}_{6} \mathrm{H}_{4} \mathrm{COO}, J=8 \mathrm{~Hz}\right), 8.39(\mathrm{~d}, 4 \mathrm{H}$, $\mathrm{C}_{6} \mathrm{H}_{4} \mathrm{COO}, J=8 \mathrm{~Hz}$ ), 8.87 (ps, $14 \mathrm{H}, \mathrm{H}_{\text {porph }}$ ) ppm. ${ }^{31} \mathrm{P}$ $\left\{{ }^{1} \mathrm{H}\right\}$ NMR $\left(162 \mathrm{MHz}, \mathrm{CDCl}_{3}\right): \delta=-54.16 \mathrm{ppm} .{ }^{13} \mathrm{C}$ $\left\{{ }^{1} \mathrm{H}\right\}$ NMR $\left(100 \mathrm{MHz}, \mathrm{CDCl}_{3}\right): \delta=52.29\left(C_{\mathrm{pta}}\right), 73.83$ $\left(C_{\mathrm{pta}}\right), 118.99,120.52,120.67,126.88,127.93,128.14$, $131.31,132.43,133.29,134.00,134.74,142.24,146.20$ $\left(C_{\text {porph }}\right), 187.42(\mathrm{COO}), 205.24(\mathrm{CO}) \mathrm{ppm} . \mathrm{IR}\left(\mathrm{CaF}_{2}\right.$, $\left.\mathrm{cm}^{-1}\right): v(\mathrm{COO}) 2,023.68$ vs, $1,978.33 \mathrm{~m}, 1,952.40$ vs, $v(\mathrm{CO}) \quad 1,605.90 \mathrm{~s}, \quad 1,588.33 \mathrm{~m}$. Anal. calcd for $\mathrm{C}_{106} \mathrm{H}_{82} \mathrm{~N}_{8} \mathrm{O}_{14} \mathrm{P}_{2} \mathrm{Ru}_{2}$ (1,956.3): C, 65.09; H, 4.23; N, 5.73. Found: C, 64.79; H, 4.18; N, 5.49. ESI-MS (positive mode): 1,349.0 $\left[\mathrm{M}-\left(\mathrm{C}_{45} \mathrm{H}_{29} \mathrm{~N}_{4}\right)+\mathrm{H}_{2} \mathrm{O}+\mathrm{H}\right]^{+}$.

Spectroscopic data for $\mathbf{4}$

Yield: $105 \mathrm{mg}$ (91\%). ${ }^{1} \mathrm{H}$ NMR $\left(400 \mathrm{MHz}, \mathrm{CDCl}_{3}\right)$ $\delta=-2.78$ (s, 8H, NH), 7.63-7.79 (m, 30H, $\left.\mathrm{H}_{\text {porph }}\right), 8.12-8.26$ (m, 26H, $\mathrm{H}_{\text {porph }}$ ), 8.38 (d, 4H, $\left.\mathrm{C}_{6} \mathrm{H}_{4} \mathrm{COO},{ }^{3} \mathrm{~J}=8 \mathrm{~Hz}\right), 8.61$ (d, $\left.4 \mathrm{H}, \mathrm{C}_{5} H_{4} \mathrm{~N},{ }^{3} \mathrm{~J}=6 \mathrm{~Hz}\right), 8.75\left(\mathrm{~d}, 4 \mathrm{H}, \mathrm{C}_{6} \mathrm{H}_{4} \mathrm{COO}\right.$, $\left.{ }^{3} J=8 \mathrm{~Hz}\right), 8.80-8.88\left(\mathrm{~m}, 20 \mathrm{H}, \mathrm{H}_{\text {porph }}\right), 8.89-8.96(\mathrm{~m}$, $\left.10 \mathrm{H}, \mathrm{H}_{\text {porph }}\right), 9.10\left(\mathrm{~m}, 4 \mathrm{H}, \mathrm{H}_{\text {porph }}\right), 9.72\left(\mathrm{~d}, 4 \mathrm{H}, \mathrm{C}_{5} H_{4} \mathrm{~N}\right.$, $\left.{ }^{3} J=6 \mathrm{~Hz}\right) . \quad{ }^{13} \mathrm{C} \quad\left\{{ }^{1} \mathrm{H}\right\} \quad \mathrm{NMR} \quad\left(100 \mathrm{MHz}, \quad \mathrm{CDCl}_{3}\right)$ $\delta=96.27,115.16,119.35,120.40,120.51,120.94,121.41$, $126.83,127.86,127.95,128.55,131.17,134.60,134.68$, $141.88,141.98,142.21,146.10,150.55,152.76,180.02$ $\left(C_{\text {porph }}\right), 180.02(C \mathrm{OO}), 204.50(C \mathrm{O}) . \mathrm{IR}\left(\mathrm{CaF}_{2}, \mathrm{~cm}^{-1}\right)$ : $v_{(\mathrm{CO})} \quad 2,024.20$ vs, $1,974.17 \mathrm{~m}, \quad 1,941.78 \quad$ vs, $\quad v_{(\mathrm{OCO})}$ 1,592.64 s. Anal. calcd for $\mathrm{C}_{180} \mathrm{H}_{116} \mathrm{~N}_{18} \mathrm{O}_{8} \mathrm{Ru}_{2} \cdot \mathrm{CHCl}_{3} \cdot \mathrm{H}_{2} \mathrm{O}$ (2,980.48): C, 72.50; H, 4.00; N, 8.41. Found: C, 72.36; H, 4.38; N, 8.24. ESI-MS (positive mode): 2,862.72 $[\mathrm{M}+\mathrm{H}]^{+}, 2,246.52\left[\mathrm{M}-\left(\mathrm{C}_{43} \mathrm{H}_{29} \mathrm{~N}_{5}\right)+\mathrm{H}\right]^{+}, 1,466.36$ $[\mathrm{M} / 2+\mathrm{Cl}]^{+}$.

Cell culture

Human colon (HT29), breast (MCF7, MDAMB231), lung (A549), ovarian (Ovcar), prostate (PC3, LnCap), and cervix (HeLa) cancer cells were obtained from the American Tissue Type Culture Collection (Manassas, VA, USA). A2780 ovarian cancer cells were obtained from the ECACC (Salisbury, UK). Human Me300 melanoma and $\mathrm{KB}$ head and neck cancer cells were kindly provided by $\mathrm{D}$. Rimoldi, Ludwig Institute of Cancer Research, Lausanne branch, and by M. Barbery-Heyob, Centre Alexis Vautrin, Nancy, France, respectively. Human uterovaginal primary 
fibroblasts were obtained from surgical biopsies of healthy patients using the explant technique [24], according to a protocol approved by the CHUV Ethics Committee and patients. HT29, MCF7, MDA-MB231, A549, PC3, LnCap, and HeLa cells were routinely grown in Dulbecco's modified Eagle's medium containing $4.5 \mathrm{~g} / \mathrm{L}$ glucose, while A2780, Ovcar, Me300, and KB cells were grown in RPMI 1640 medium. All were supplemented with 10\% heat-inactivated fetal calf serum and with antibiotics (all from Gibco, Basel, Switzerland). The organometallic complexes were dissolved in dimethyl sulfoxide and then diluted in complete medium to the required concentration. The dimethyl sulfoxide concentration did not exceed $1 \%$ $\mathrm{v} / \mathrm{v}$ and this concentration did not show any effects on cells.

Evaluation of uptake and toxicity of the complexes

Cells in 48-well plates (Costar) were exposed at $37{ }^{\circ} \mathrm{C}$ to increasing concentrations of complexes in complete culture medium for $48 \mathrm{~h}$. After they had been washed with phosphate-buffered saline (PBS), the supernatants were replaced with fresh medium and the cell-associated content was evaluated by its porphyrin characteristic fluorescence in a thermostated fluorescence microplate reader (Cytofluor, PerSeptive BioSystems), with excitation and emission filters set at $409 \pm 5$ and $645 \pm 10 \mathrm{~nm}$, respectively, essentially as previously described [25, 26]. Cell survival was measured using the 3-(4,5-dimethyl-2-thiazoyl)-2,5-diphenyltetrazolium bromide (MTT) test. MTT (Merck) was added at $250 \mu \mathrm{g} / \mathrm{mL}$ and incubation was continued for $2 \mathrm{~h}$, as previously described [19]. Then the cell culture supernatants were removed, the cell layer was dissolved in $i$-PrOH/0.04 N HCl, and the absorbance at $540 \mathrm{~nm}$ was measured in a 96-well multiwell-plate reader (iEMS Reader MF, Labsystems, Bioconcept, Switzerland) and compared with the values of control cells incubated without complexes. Experiments were conducted in triplicate wells and repeated at least twice.

\section{Fluorescence microscopy}

Cells were grown on histological slides in complete medium and exposed to the complexes overnight at $25 \mu \mathrm{M}$ concentrations. Slides were washed and incubated with the nuclear stain 4',6'-diamidino-2-phenylindolyl hydrochloride (DAPI; Roche Diagnostics, Mannheim, Germany, $1 \mu \mathrm{g} / \mathrm{mL}$ in PBS) for $10 \mathrm{~min}$ at $37{ }^{\circ} \mathrm{C}$, and examined in PBS under a fluorescence microscope (Axioplan2, Carl Zeiss, Feldbach, Switzerland) and filters were set at 365nm excitation light (BP 365/12, FT 395, LP 397) for DAPI and 535-nm excitation light (BP 510-560, FT 580, LP 590) for porphyrins as previously described [19, 20, 25].
Photodynamic therapy

Cells in 96-well plates (Costar) were incubated in the dark in complete medium with $2.5 \mu \mathrm{M}$ complexes for $24 \mathrm{~h}$. Culture medium was replaced by medium without phenol red (Gibco) containing 5\% fetal calf serum. Cells were irradiated with a laser at $652 \mathrm{~nm}$ (Ceralas 652 laser diode, Biolitec, Jena, Germany) coupled to with a frontal diffuser (Medlight, Ecublens, Switzerland), at an irradiance of $30 \mathrm{~mW} / \mathrm{cm}^{2}$ and with light doses ranging from 2.5 to $20 \mathrm{~J} /$ $\mathrm{cm}^{2}$ as previously described [19, 20, 24, 25]. Cell survival was assessed with the MTT assay $24 \mathrm{~h}$ after the end of the irradiation and compared with values for cells irradiated without the complexes as previously described [19]. The $\mathrm{LD}_{50}$ (light dose necessary to induce $50 \%$ inhibition of cell growth) values were determined after linearization using the medium effect algorithm as described elsewhere [27].

\section{Results}

Syntheses and characterization

The thermal reaction of $\left[\mathrm{Ru}_{3}(\mathrm{CO})_{12}\right]$ with an excess of the corresponding carboxylic acid $\mathrm{HO}_{2} \mathrm{CR}\left(\mathrm{R}\right.$ is $\mathrm{CH}_{3}$ and $\mathrm{C}_{44} \mathrm{H}_{29} \mathrm{~N}_{4}$ ) in refluxing THF yields a solution containing the corresponding THF complexes $\left[\mathrm{Ru}_{2}(\mathrm{CO})_{4}\left(\mu_{2}-\eta^{2}-\right.\right.$ $\left.\mathrm{O}_{2} \mathrm{CR}\right)_{2}(\mathrm{THF})_{2}$ ]. These labile intermediates react easily with two-electron ligands to give the stable triphenylphosphine, 1,3,5-triaza-7-phosphatricyclo[3.3.1.1]decane (pta), or porphyrin-derived pyridyl analogues (Fig. 1). Complexes 1-4 were isolated by precipitation and characterized by IR, NMR, and ESI-MS as well as by elemental analysis.

All compounds exhibit in the $v_{(\mathrm{CO})}$ region of the IR spectrum the characteristic three-band pattern of the $\mathrm{Ru}_{2}(\mathrm{CO})_{4}$ sawhorse unit, observed in all complexes of this type [21, 28]. Similarly, for the two carboxylato bridges only one $v_{(\mathrm{OCO})}$ absorption is observed, in accordance with the spectra of other $\left[\mathrm{Ru}_{2}(\mathrm{CO})_{4}\left(\mu_{2}-\eta^{2}-\mathrm{O}_{2} \mathrm{CR}\right)_{2} \mathrm{~L}_{2}\right]$ complexes [21, 28].

Whatever the position of the porphyrin at the sawhorse unit is, as axial ligands or as carboxylato bridges, the chemical shift of the signal corresponding to the $\mathrm{NH}$ protons in the ${ }^{1} \mathrm{H}$ NMR spectra remains unchanged ( $\delta=-2.75 \mathrm{ppm}$ for $\mathbf{1}$ and $\mathbf{2},-2.74 \mathrm{ppm}$ for $\mathbf{3}$, and -2.78 ppm for 4). In the ${ }^{13} \mathrm{C}\left\{{ }^{1} \mathrm{H}\right\}$ NMR spectra, the peaks of the terminal carbonyl groups and of the carboxylato bridges are found around 180 and 205 ppm, respectively, again in agreement with those reported in the literature [29].

The electronic spectra of porphyrin complexes 1-3 exhibit the typical four Q bands between 510 and $650 \mathrm{~nm}$ and the intense Soret band around $420 \mathrm{~nm}$ (Table 1). The 
Fig. 1 Structures of diruthenium tetracarbonyl porphyrin complexes 1-4

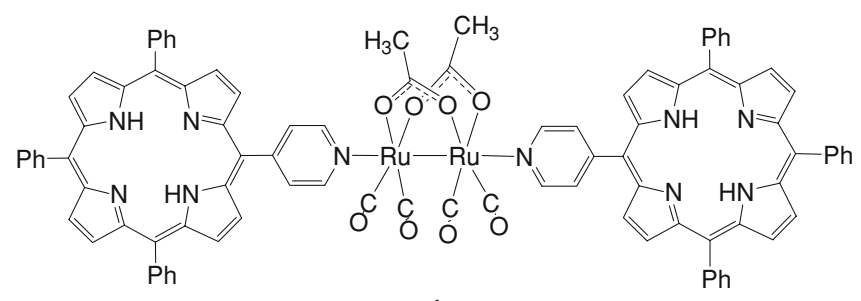

1

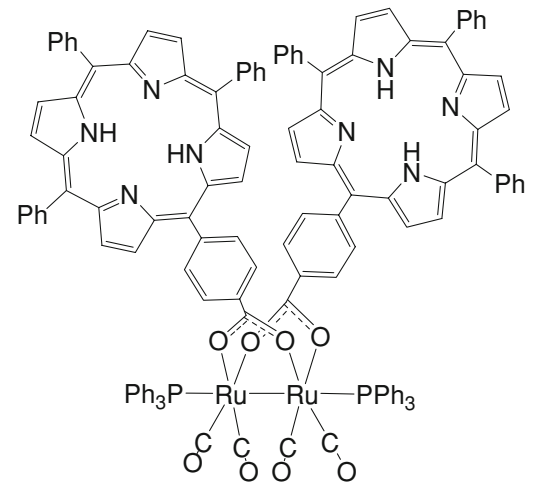

2

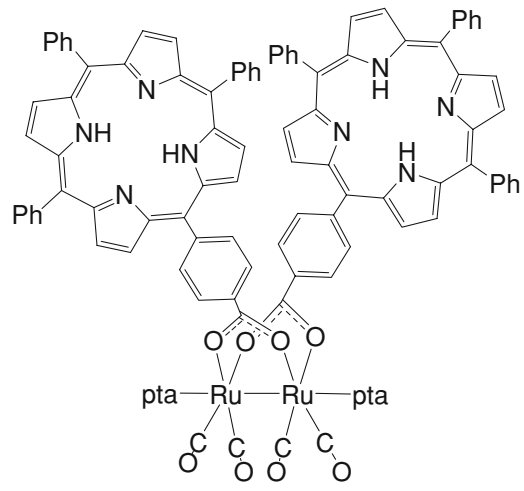

3

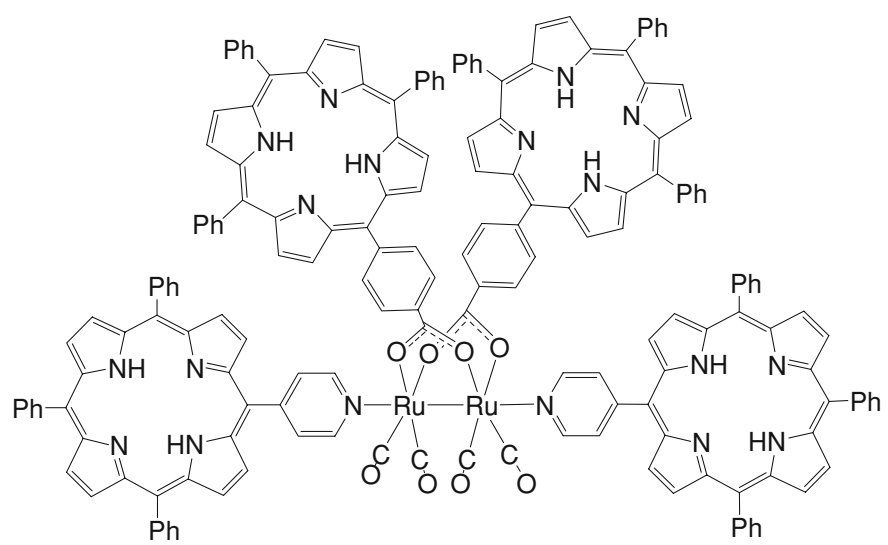

4

Table 1 UV-vis maximum absorption wavelength $(\mathrm{nm})$ determined in dichloromethane, fluorescence quantum yields at $648 \mathrm{~nm}\left(\phi_{\mathrm{f}}^{648}\right)$ in methanol, and singlet oxygen quantum yields $\left(\phi^{1} \mathrm{O}_{2}\right)$ in ethanol

\begin{tabular}{llllllrr}
\hline Compound & Soret band & Q band IV & Q band III & Q band II & Q band I & $\phi_{\mathrm{f}}^{648}(\%)$ & $\phi^{1} \mathrm{O}_{2}(\%)$ \\
\hline $\mathbf{1}$ & 419 & 514 & 550 & 590 & 647 & 9.0 & 54 \\
$\mathbf{2}$ & 419 & 515 & 550 & 590 & 646 & 6.9 & 57 \\
$\mathbf{3}$ & 419 & 515 & 549 & 590 & 648 & 10.0 & 48 \\
\hline
\end{tabular}

See Fig. 1 for the structures of $\mathbf{1 - 3}$

absorption bands of the uncoordinated porphyrin units remain unchanged upon coordination to the dinuclear sawhorse-type moiety, thus suggesting that there is no perturbation of the porphyrin $\pi$-orbitals upon coordination.

The redox behavior of complexes 1, 2 and $\mathbf{4}$ was studied by cyclic voltammetry at a platinum disc electrode. The pertinent data are summarized in Table 2. The redox behavior of 1 can be regarded as a superposition of the redox response of the molecular parts: the diruthenium core gives rise to an irreversible oxidation wave, while the porphyrin pendants undergo an oxidation and a two consecutive reduction process. The assignment of the most positive oxidation peak was not possible from the data available. The redox changes attributable to the porphyrin 
Table 2 Summary of the electrochemical data for 1, 2 and 4 (see Fig. 1 for the structures)

\begin{tabular}{ll}
\hline Compound & $E(\mathrm{~V})$ \\
\hline $\mathbf{1}^{\mathrm{a}}$ & $\mathrm{A}+0.56(\mathrm{ir}), \mathrm{B}+0.65(\mathrm{r}), \mathrm{C}+0.93(\mathrm{r}) ; \mathrm{D}-1.61(\mathrm{r})$, \\
& $\mathrm{E}-2.02^{\mathrm{b}, \mathrm{c}}$ \\
$\mathbf{2}^{\mathrm{d}}$ & $\mathrm{A}+0.22,^{\mathrm{b}, \mathrm{e}} \mathrm{B}+0.45(\mathrm{ir}), \mathrm{C}+0.59(\mathrm{r}), \mathrm{D}+0.87(\mathrm{r}) ;$ \\
& $\mathrm{E}-1.67(\mathrm{r}), \mathrm{F} \approx-2.0$ \\
$\mathbf{4}^{\mathrm{f}}$ & $\mathrm{A}+0.25,{ }^{\mathrm{g}} \mathrm{B}+0.47(\mathrm{ir}), \mathrm{C}+0.58(\mathrm{r}), \mathrm{D}+0.89(\mathrm{r}) ;$ \\
& $\mathrm{E}-1.79(\mathrm{r}), \mathrm{F} \approx-2.3^{\mathrm{c}}$ \\
\hline
\end{tabular}

The potentials are quoted relative to a ferrocene/ferrocenium reference. Peak potentials are given for irreversible (ir) processes: anodic peak potential $\left(E_{\mathrm{pa}}\right)$ for oxidations, cathodic peak potential $\left(E_{\mathrm{pc}}\right)$ for reductions. The potential for reversible $(r)$ couples is defined as the mean of the anodic and cathodic peak potentials: $E^{\circ \prime}=1 / 2\left(E_{\mathrm{pa}}+E_{\mathrm{pc}}\right)$

a Additional wave: $\mathrm{F} E_{\mathrm{pa}} \approx+0.23 \mathrm{~V}$, ${ }^{\mathrm{b}}$ see text, ${ }^{\mathrm{c}} E_{\mathrm{pc}}$ is given, d additional waves: $\mathrm{G}-1.52$ (ir), $\mathrm{H} E_{\mathrm{pa}} \approx+1.18 \mathrm{~V},{ }^{\mathrm{e}} E^{\mathrm{ol}}$ is given, ${ }^{\mathrm{f}}$ additional wave: $\mathrm{G}-1.56$ (ir), ${ }^{\mathrm{g}} E_{\mathrm{pa}}$ is given

moiety are reversible at scan rates of $0.1-1.0 \mathrm{~V} / \mathrm{s}$ and occur independently at both porphyrin pendants (i.e., as a sum of two identical one-electron waves), which rules out any significant electronic coupling between the porphyrin moieties. The second reduction is probably one-electron reduction as well but occurs at the onset of the base electrolyte decomposition. It is worth noting that the B-D-E waves (Table 2) are observed in a similar pattern and at roughly similar potentials as for free 5-(4-pyridyl)10,15,20-triphenyl-21,23H-porphyrin [30]. This indicates that coordination via the peripheral pyridine moiety has only a minor influence (e.g., inductive) on the redox properties of the porphyrin framework.

Complex 2 shows two oxidations possibly attributable to the diruthenium core (A and B) followed by two reversible oxidations localized most likely at the porphyrin units (C and D). The subsequent oxidation (wave $\mathrm{H}$ ) occurs

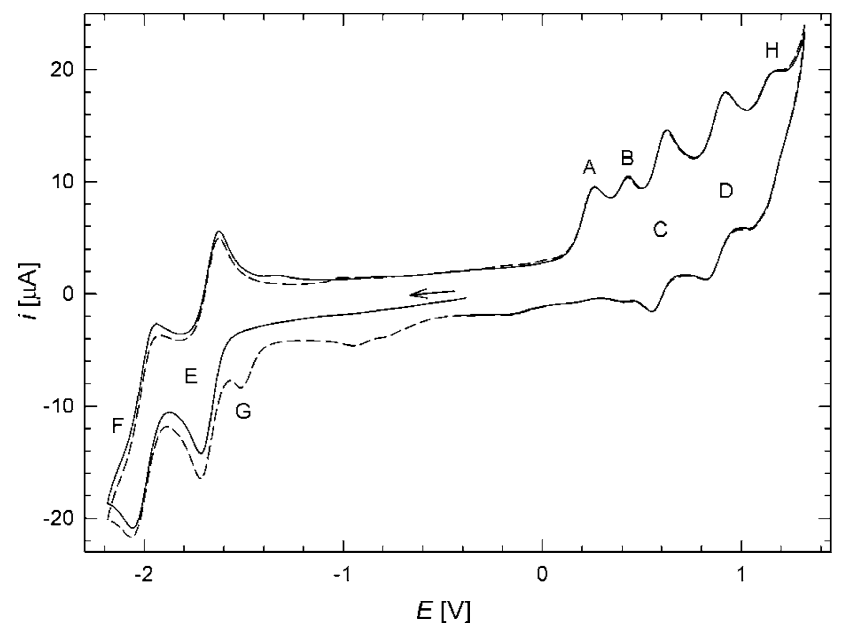

Fig. 2 The cyclic voltammogram of 2 recorded at $0.1-\mathrm{V} / \mathrm{s}$ scan rate. Note the difference between the first cycle (solid line) and the second cycle (dashed line) already at the onset of base electrolyted decomposition (Fig. 2). The first oxidation (A) is observed with full reversibility down to $0.1-\mathrm{V} / \mathrm{s}$ scan rate when scanned separately. Increasing the switching potential beyond the second ( $\mathrm{B}$, irreversible) and third $(\mathrm{C}$, reversible) oxidations makes the first oxidative wave quasi-reversible (the peak current ratio $i_{\mathrm{pa}} / i_{\mathrm{pc}}$ increases with the scan rate) and fully irreversible (up to $5 \mathrm{~V} / \mathrm{s}$ ), respectively. The redox properties of $\mathbf{4}$ correspond to the sum of those of $\mathbf{1}$ and $\mathbf{2}$. Therefore, because of the similar redox behavior of the individual parts, the individual redox waves overlap, forming broad redox waves that do not allow any detailed analysis.

\section{Biological assays}

The effect of the organometallic porphyrin complexes 1-3 was investigated in vitro in human normal fibroblastic cells and in several human cancer cells: HeLa cervix, A2780 and Ovcar ovarian, A549 pulmonary, Me300 melanoma, PC3 and LnCap prostate, KB head and neck, MCF7 and MDAMB231 breast, as well as HT29 colon cancer cells. The poor solubility of $\mathbf{4}$ did not allow its assessment. Cells were exposed for $48 \mathrm{~h}$ to increasing concentrations of compounds 1-3 and their survival was determined using the MTT cell survival assay. Representative results in human normal fibroblastic cells and A549, HeLa, and A2780 cancer cells are shown in Fig. 3 (not shown for the other cells). In the absence of laser exposure (dark toxicity), compounds 1-3 did not display any cytotoxic effect in all the cell types up to $100 \mu \mathrm{M}$ concentration.

The uptake of compounds 1-3 was also studied by quantification of the characteristic fluorescence of porphyrin derivatives $\left(\lambda_{\mathrm{exc}} / \lambda_{\mathrm{em}}=410 \mathrm{~nm} / 650 \mathrm{~nm}\right)$ in cells exposed to the complexes at concentrations from 5 to $100 \mu \mathrm{M}$. The results revealed that HeLa and A2780 cells presented a good uptake profile, whereas other normal and cancer cells presented a very low uptake of the compounds (Fig. 3). These results were checked by fluorescence microscopy; the fluorescence associated with porphyrin appears red, whereas cell nuclei appear blue with DAPI counterstaining (Fig. 4). For these compounds in all cell lines, nuclear fragmentation was not observed, suggesting the absence of cell apoptosis, at least for this time course. Good accumulation of porphyrins in the cytoplasm of HeLa, A2780, and Ovcar (not shown) cells was observed but was not found in other cell types (only human normal fibroblastic cells and A549 pulmonary cell line being shown).

The phototoxic efficacy of the porphyrin complexes was assessed at $2.5 \mu \mathrm{M}$ concentration. Cells were incubated for $24 \mathrm{~h}$ with compounds 1-3 before irradiation at $652 \mathrm{~nm}$ $\left(30 \mathrm{~mW} / \mathrm{cm}^{2}\right)$ and light doses from 2.5 to $20 \mathrm{~J} / \mathrm{cm}^{2}$. MTT cell survival test was performed after a further incubation 
Fig. 3 Porphyrin accumulation in human cells and cytotoxicity in the dark of 1-3. Cells were exposed to increasing concentrations of diruthenium tetracarbonyl porphyrin complexes and the increase of characteristic porphyrin fluorescence was recorded after $48 \mathrm{~h}$ of incubation (filled squares 1, filled circles $\mathbf{2}$, filled triangles 3). The 3-(4,5dimethyl-2-thiazoyl)-2,5diphenyltetrazolium bromide (MTT) cell survival test was performed at the end of the incubation and the values obtained were compared with values of nonincubated cells (open squares $\mathbf{1}$, open circles $\mathbf{2}$, open triangles $\mathbf{3}$ )

Fig. 4 Fluorescence microscopy of human cells exposed to diruthenium tetracarbonyl porphyrin complexes 1-3. Cells were grown on histological slides and incubated with complexes at $25 \mu \mathrm{M}$ concentration overnight in the dark. Compounds appear as red fluorescence spots and cell nuclei as blue fluorescence after $4^{\prime}, 6^{\prime}$-diamidino-2phenylindolyl hydrochloride counterstaining
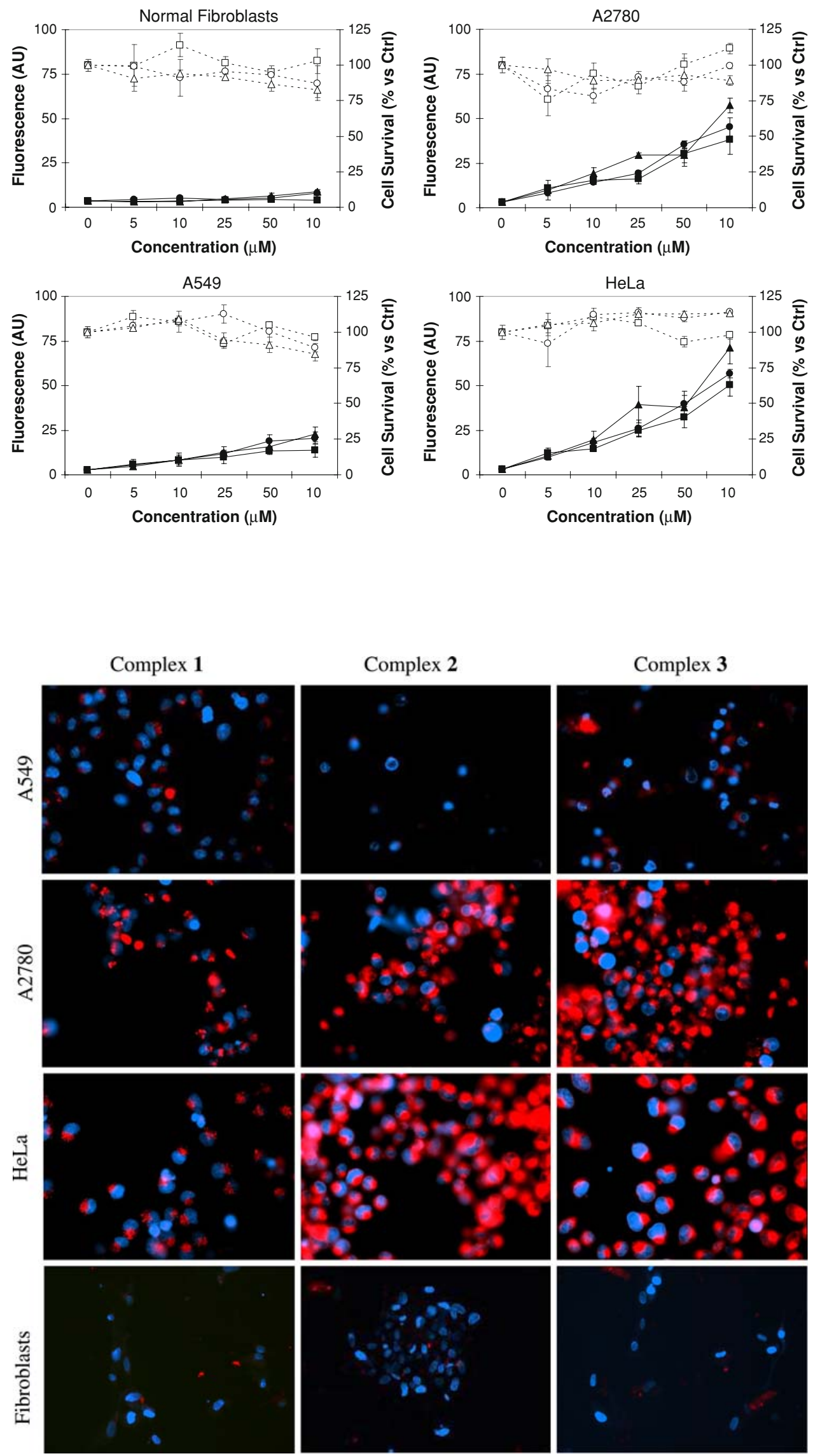

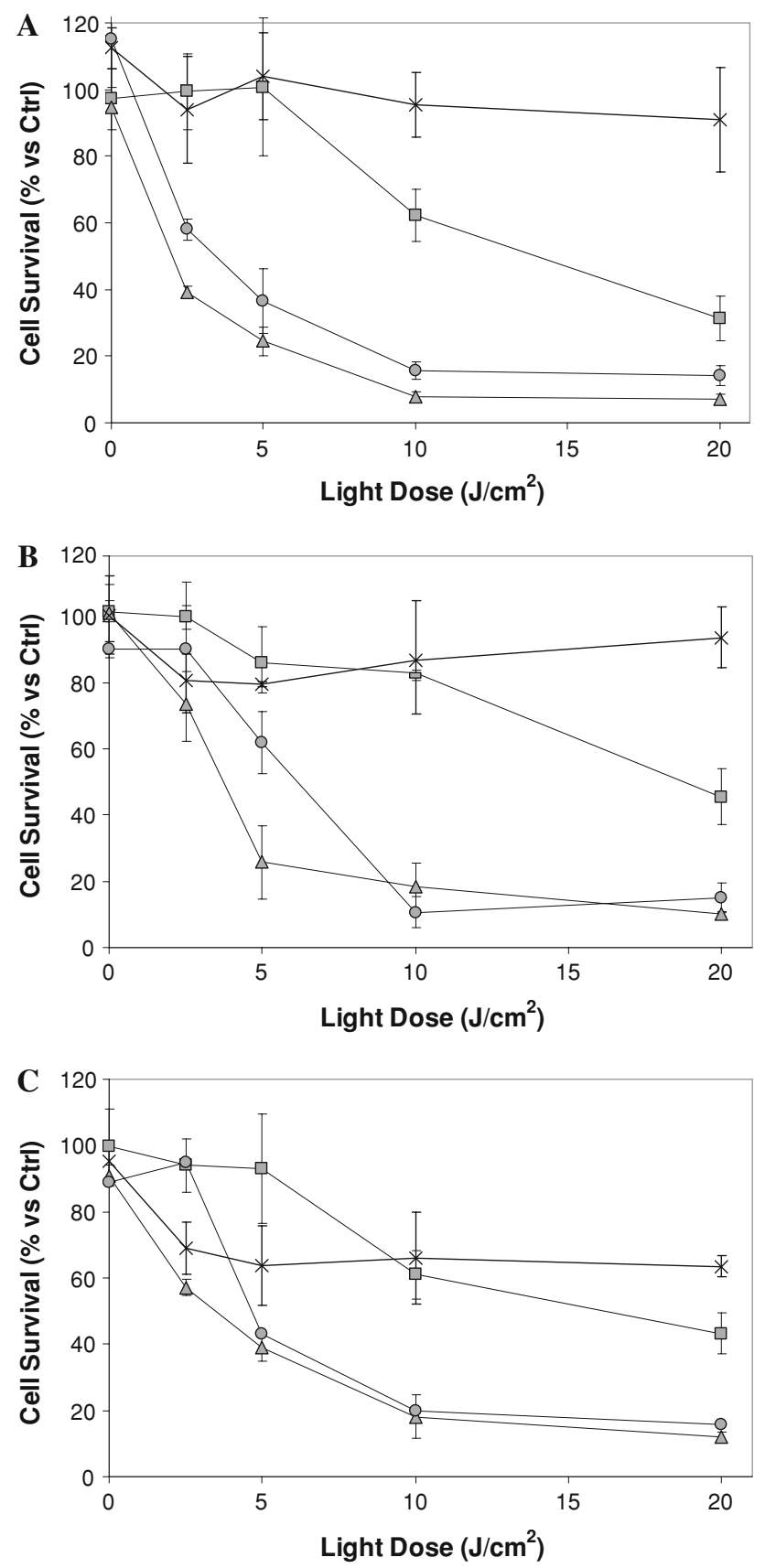

Fig. 5 Photodynamic activity of compounds $\mathbf{1}(\mathbf{a}), \mathbf{2}(\mathbf{b})$, and $\mathbf{3}(\mathbf{c})$ in human cell lines. Cells were exposed to compounds $(2.5 \mu \mathrm{M})$ in the dark for $24 \mathrm{~h}$ before being exposed to increasing doses of light at $652 \mathrm{~nm}$. Then the amount of metabolically active cells was determined $24 \mathrm{~h}$ later by the MTT assay. Cells not exposed to the compounds, but irradiated, were used as controls. A549 (squares), HeLa (triangles), A2780 (circles), and normal fibroblasts (crosses)

of $24 \mathrm{~h}$. Cells treated in identical conditions but kept in the dark, were used as controls for phototoxicity. Untreated human cells were not photosensitive in the absence of complexes (results not shown). The viability of cells exposed to 1-3 and light-irradiated is shown in Fig. 5 and the corresponding $\mathrm{LD}_{50}$ values (light dose necessary to
Table $3 \mathrm{LD}_{50}$ values of human cells exposed to diruthenium tetracarbonyl porphyrin complexes 1-3

\begin{tabular}{lllll}
\hline \multirow{2}{*}{ Complexes } & \multicolumn{2}{l}{$\mathrm{LD}_{50}\left(\mathrm{~J} / \mathrm{cm}^{2}\right)$} & & \\
\cline { 2 - 5 } & Fibroblasts & A549 & HeLa & A2780 \\
\hline $\mathbf{1}$ & $>30$ & 14.7 & 1.5 & 2.9 \\
$\mathbf{2}$ & $>30$ & 18.6 & 3.6 & 5.4 \\
$\mathbf{3}$ & $>30$ & 15.7 & 3.1 & 6.7 \\
\hline
\end{tabular}

Cells were exposed to the complexes $(2.5 \mu \mathrm{M})$ for $24 \mathrm{~h}$ in the dark, and were then illuminated with a red laser $(\lambda=652 \mathrm{~nm})$. The 3-(4,5dimethyl-2-thiazoyl)-2,5-diphenyltetrazolium bromide cell survival test was performed $24 \mathrm{~h}$ after the irradiation. The $\mathrm{LD}_{50}$ values (light dose necessary to inhibit $50 \%$ cell survival) were determined using the medium effect algorithm [27]

inhibit $50 \%$ cell survival) are presented in Table 3. The complexes were efficient in HeLa and A2780 cells with $1.5<\mathrm{LD}_{50}<6.5 \mathrm{~J} / \mathrm{cm}^{2}$, whereas, phototoxicities in other cell types were very low with $\mathrm{LD}_{50}$ values of more than $15 \mathrm{~J} / \mathrm{cm}^{2}$. In all cancer cell lines, complex 1 appeared to be slightly more efficient. Thus, the phototoxicity results are coherent with uptake results which showed that the compounds were only taken up by HeLa and A2780 cell lines.

Thus, these types of compound present a selectivity pattern toward female reproductive cancer cells compared with other types of cancer cells but also compared with human normal primary fibroblasts.

\section{Discussion}

In the present study, our aim was to develop molecules able to combine the photosensitizing properties of porphyrins with the organometallic effects of diruthenium carboxylate as potential drug candidates for cancer therapy as we have already reported for arene-ruthenium(II) moieties coordinated to pyridylporphyrin derivatives $[19,20]$. The cytotoxicities of the complexes were tested in human normal fibroblasts and in several human cancer cell lines. Our new organometallic-porphyrin complexes displayed no cytotoxicities in the dark for concentrations up to $100 \mu \mathrm{M}$ for all the cell lines tested. This is in accordance with non-porphyrin-containing diruthenium tetracarbonyl sawhorse-type complexes which show no cytotoxicity on the A2780 ovary carcinoma cell line [31] and with other diruthenium carboxylate derivatives which presented some $\mathrm{IC}_{50}$ values greater than $120 \mu \mathrm{M}$ in the HeLa cell line [32].

Interestingly, uptake studies revealed that our complexes are only taken up by human HeLa cervix and A2780 ovary carcinoma cell lines and not by the other human normal or cancer cell lines. These data were established using the characteristic fluorescence of porphyrin derivatives. Fluorescence microscopy studies also demonstrated 
that the complexes are taken up by HeLa, Ovcar, and A2780 cells and concentrate in the cell cytoplasm and organelles, but not in the nucleus, as did our previously reported compounds $[19,20]$ but this contrasts with some ruthenium-based drugs known to accumulate in the nucleus $[33,34]$.

Photodynamic studies provided coherent results compared with uptake studies since our complexes induce phototoxicities in HeLa cervix and A2780 ovary carcinoma cell lines and not in other cancer and normal fibroblast cells. Moreover, our complexes appeared to be efficient since they are active at low concentration $(2.5 \mu \mathrm{M})$ and at low light dose $\left(1.5<\mathrm{LD}_{50}<6.5 \mathrm{~J} / \mathrm{cm}^{2}\right)$. In both cell lines, complex 1 was found to be slightly more active than complexes $\mathbf{2}$ and $\mathbf{3}$. The reasons for this cell specificity remain unknown but must be attributed to the diruthenium structure since the porphyrin alone does not have such specificity properties. Other organometallic compounds conjugated to hydrophobic heterocycles have already been demonstrated to present a specificity to breast estrogen receptors [35, 36]. Although, this is not the case for our compounds since both MCF7 (estrogen-receptor positive) and MDA-MB231 (estrogen-receptor negative) breast cancer cell lines were unable to take up our compounds, we hypothesize the targeting of another specific receptor of female reproductive cancer cells since only cervix and ovarian cancers are able to take up the complexes. The reasons for this specificity are currently under investigation, but at the moment it remains unclear why the complexes are so selective. However, these new compounds are efficient photosensitizers and could provide new hints for the design of organometallodrugs specific for cancers of the female reproductive system that do not target normal cells.

Acknowledgments We thank C. Frochot and S. Hupont (DCPR, ENSIC, Nancy, France) for their assistance in determining the singlet oxygen quantum yields. This work was financially supported by the COST program D39 "Metallo-drug design and action." We thank the Fondation Suisse pour la Lutte Contre le Cancer (grant no. 227) for financing the purchase of the photodynamic therapy laser and Johnson Matthey Research Centre for a generous loan of ruthenium chloride hydrate. This work is also a part of the research project MSM0021620857 supported by Ministry of Education of the Czech Republic.

\section{References}

1. Brown SB, Brown EA, Walker I (2004) Lancet Oncol 5:497-508

2. Dolmans DEJGJ, Fukumura D, Jain (2003) Nat Rev Cancer 3:380-387

3. Nyman ES, Hynninen PH (2004) J Photochem Photobiol B 73:128
4. Qiang YG, Zhang XP, Li J, Huang Z (2006) Chin Med J 119:845-857

5. Juillerat-Jeanneret L (2006) Trends Cancer Res 2:71-84

6. Barrrett AJ, Kennedy JC, Jones RA, Nadeau P, Pottier RH (1990) J Photochem Photobiol B 6:309-323

7. Rosenberg B, van Camp L, Krigas T (1965) Nature 205:698-699

8. Reedijk J (1996) Chem Commun 801-806

9. Wong E, Giandomenico CM (1999) Chem Rev 99:2451-2466

10. Jakupec MA, Galanski M, Keppler BK (2003) Rev Physiol Biochem Pharmacol 146:1-53

11. Galanski M, Arion VB, Jakupec MA, Keppler BK (2003) Curr Pharm Des 9:2078-2089

12. Ang WH, Dyson PJ (2006) Eur J Inorg Chem 4003-4018

13. Melchart M, Sadler PJ (2006) In: Jaouen G (ed) Bioorganometallics. Wiley-VCH, Weinheim

14. Lottner C, Bart KC, Bernhardt G, Brunner H (2002) J Med Chem 45:2064-2078

15. Lottner C, Bart KC, Bernhardt G, Brunner H (2002) J Med Chem 45:2079-2089

16. Kim YS, Song R, Kim DH, Jun MJ, Sohn YS (2003) Bioorg Med Chem 11:1753-1760

17. Lottner C, Knuechel R, Bernhardt G, Brunner H (2004) Cancer Lett 203:171-180

18. Lottner C, Knuechel R, Bernhardt G, Brunner H (2004) Cancer Lett 215:167-177

19. Schmitt F, Govindaswamy P, Süss-Fink G, Ang WH, Dyson PJ, Juillerat-Jeanneret L, Therrien B (2008) J Med Chem 51:18111816

20. Schmitt F, Govindaswamy P, Zava O, Süss-Fink G, JuilleratJeanneret L, Therrien B (2009) J Biol Inorg Chem 14:101-109

21. Crooks GR, Johnson BFG, Lewis J, Williams IG, Gamlen G (1969) J Chem Soc A 2761-2766

22. Bruce MI, Jensen CM, Jones NL (1989) Inorg Synth 26:259-261

23. Daigle DJ (1998) Inorg Synth 32:40-45

24. Poncet S, Meyer S, Richard C, Aubert JD, Juillerat-Jeanneret L (2005) Am J Obstet Gynecol 192:426-432

25. Vallinayagam R, Schmitt F, Barge J, Wagnières G, Wenger V, Neier R, Juillerat-Jeanneret L (2008) Bioconjug Chem 19:821839

26. Gurba P, Vallinayagam R, Schmitt F, Furrer J, Juillerat-Jeanneret L, Neier R (2008) Synthesis 24:3957-3962

27. Schneider R, Schmitt F, Frochot C, Fort Y, Lourette N, Guillemin F, Muller JF, Barberi-Heyob M (2005) Bioorg Med Chem 13:2799-2808

28. Johnson BFG, Johnston RD, Lewis J, Williams IG (1971) J Chem Soc A 689-691

29. Micoli F, Salvi L, Salvini A, Frediani P, Giannelli C (2005) J Organomet Chem 690:4867-4877

30. Funatsu K, Kimura A, Imamura T, Ichimura A, Sasaki Y (1997) Inorg Chem 36:1625-1635

31. Auzias M, Mattsson J, Therrien B, Süss-Fink G (2009) Z Anorg Allg Chem 635:115-119

32. Van Rensburg CE, Kreft E, Swarts JC, Dalrymple SR, MacDonald DM, Cooke MW, Aquino MA (2002) Anticancer Res 22:889-892

33. Pongratz M, Schluga P, Jakupec MA, Arion VB, Hartinger CG, Allmaier G, Keppler BK (2004) J Anal At Spectrom 19:46-51

34. Vock CA, Ang WH, Scolaro C, Phillips AD, Lagopoulos L, Juillerat-Jeanneret L, Sava G, Scopelliti R, Dyson PJ (2007) J Med Chem 50:2166-2175

35. Pigeon $\mathrm{P}$, Top S, Vessières A, Huché M, Hillard EA, Salomon E, Jaouen G (2005) J Med Chem 48:2814-2821

36. Vessières A, Top S, Beck W, Hillard E, Jaouen G (2006) Dalton Trans 529-541 